\title{
Esophageal squamous cell carcinoma presenting as submucosal lesion with repeatedly negative endoscopic biopsies
}

\author{
Narendra S. Choudhary, Rinkesh K. Bansal, Rajesh Puri, Mridula Guleria ${ }^{1}$, Randhir Sud \\ Institute of Digestive and Hepatobiliary Sciences, 'Department of Cytopathology, Medanta, The Medicity, Gurgaon, Haryana, India
}

\begin{abstract}
A 74-year-old male presented with dysphagia for 2 months. Computed tomography revealed irregular wall thickening of the esophagus at T3 to T5 level. He underwent gastroscopy which revealed a submucosal bulge with normal mucosa at $25 \mathrm{~cm}$ from incisors. Repeated biopsies were taken, all were negative for malignancy. The patient underwent endoscopic ultrasound, and fine-needle aspiration was taken which was suggestive for squamous cell carcinoma.

Key words Dysphagia, endoscopic ultrasound fine-needle aspiration, squamous cell carcinoma
\end{abstract}

\section{Introduction}

This case had normal looking esophageal mucosa and repeatedly negative mucosal biopsies that make it extremely uncommon presentation. We established the importance of EUS guided fine needle aspiration of atypical submucosal lesions.

\section{Case Report}

A 74-year-old male presented with dysphagia for 2 months. He underwent computed tomography (CT) outside which revealed irregular wall thickening of the esophagus at T3 to T5 level. A gastroscopy was done outside which revealed a submucosal bulge with normal mucosa at $25 \mathrm{~cm}$ from incisors, and biopsies were taken which did not reveal malignancy. Endoscopic biopsies from bulge area were taken again; however, there was similar result. The patient was refereed for endoscopic ultrasound (EUS). An endoscopy was done before EUS which revealed a submucosal lesion causing luminal narrowing for a

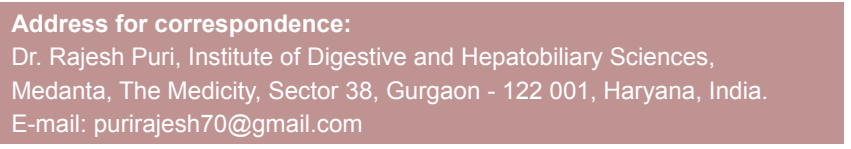

\begin{tabular}{|l|c|}
\hline \multicolumn{2}{|c|}{ Access this article online } \\
Website: & Quick Response Code \\
www.jdeonline.in & \\
\hline &
\end{tabular}

distance of $2-3 \mathrm{~cm}$ [Figure 1]. There was a linear ulcer below this lesion [Figure 2]. Endoscopic biopsies were taken from the area of submucosal bulge as well as ulcer, which revealed nonspecific inflammation, and there was no evidence of malignancy as well. EUS was done using GF-UCT140 linear echoendoscope (EUS scope, Olympus, Tokyo, Japan), which

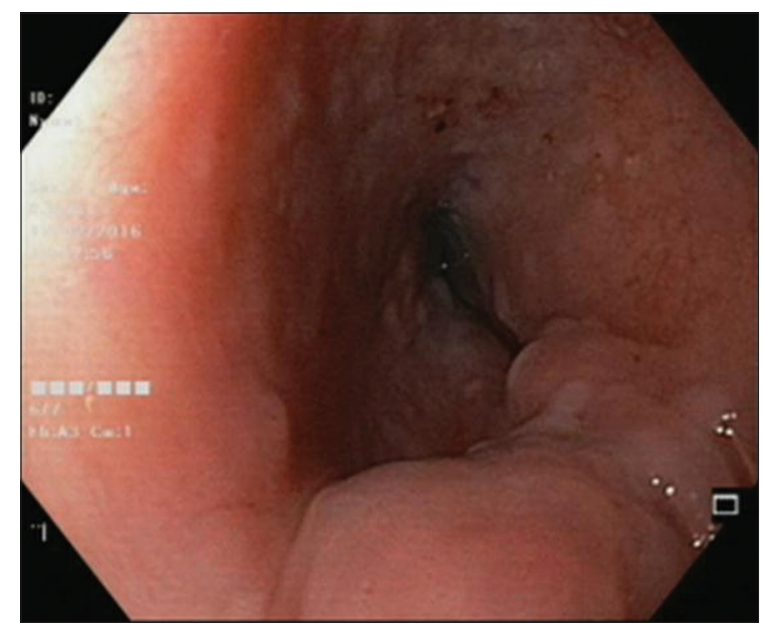

Figure 1: Endoscopy image showing submucosal lesion

This is an open access article distributed under the terms of the Creative Commons Attribution-NonCommercial-ShareAlike 3.0 License, which allows others to remix, tweak, and build upon the work non-commercially, as long as the author is credited and the new creations are licensed under the identical terms.

For reprints contact: reprints@medknow.com

How to cite this article: Choudhary NS, Bansal RK, Puri R, Guleria M, Sud R. Esophageal squamous cell carcinoma presenting as submucosal lesion with repeatedly negative endoscopic biopsies. J Dig Endosc 2016;7:153-4. 


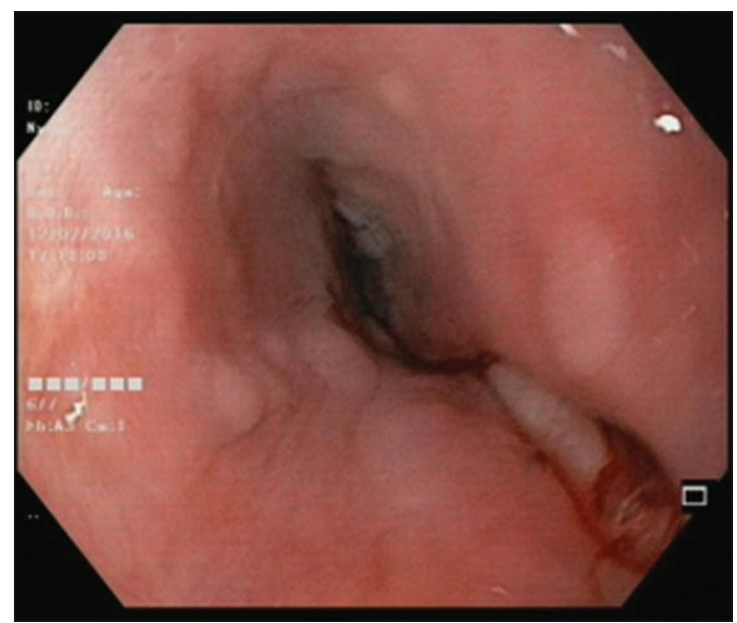

Figure 2: A linear ulcer below submucosal lesion

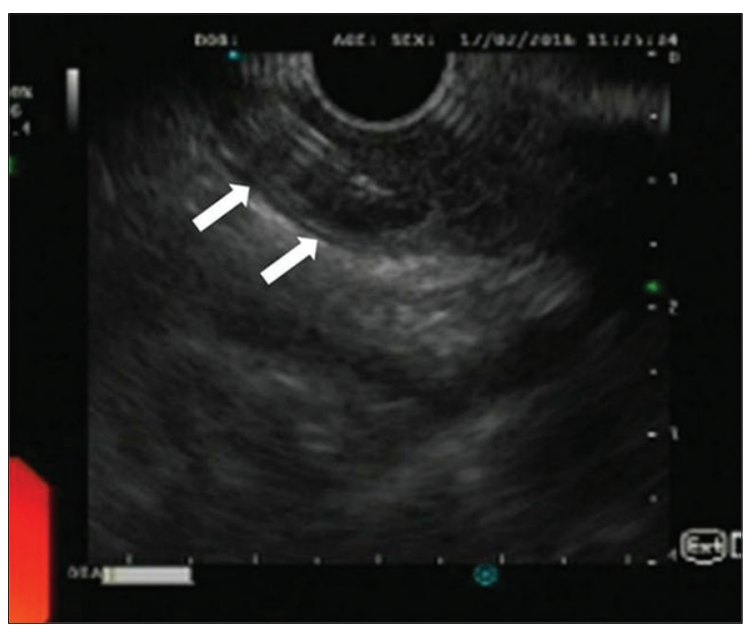

Figure 4: Linear endoscopic ultrasound shows a loss of wall layer pattern and thickened wall (layer 4 marked by white arrows), fine-needle aspiration needle can be seen

revealed $1.8 \mathrm{~cm} \times 1.5 \mathrm{~cm}$ sized hypoechoic lesion arising from the second layer with a loss of wall layer pattern from deeper layers [Figures 3 and 4]. It was involving the fourth layer of the esophagus. The lesion was T2N0. EUS-guided fine-needle aspiration was taken with $22-\mathrm{G}$ needle (2 passes) from submucosal lesion. Cytopathological report showed sheets and clusters of dysplastic cells resembling squamous cells; stain for keratin was positive [Figure 5]. A diagnosis of squamous cell carcinoma of the esophagus was made. CT of the chest and abdomen was done which does not reveal any metastasis.

Squamous cell carcinoma is common esophageal malignancy and one of the most common malignancies around the world. ${ }^{[1]}$ There is a single case report of metastatic esophageal squamous cell carcinoma presenting as submucosal gastric lesion. ${ }^{[2]}$ A varicoid variety of esophageal carcinoma has been reported; however, mucosa remains abnormal in such cases, and diagnosis can be made by endoscopic biopsies. ${ }^{[3]}$ The present case had normal looking mucosa and

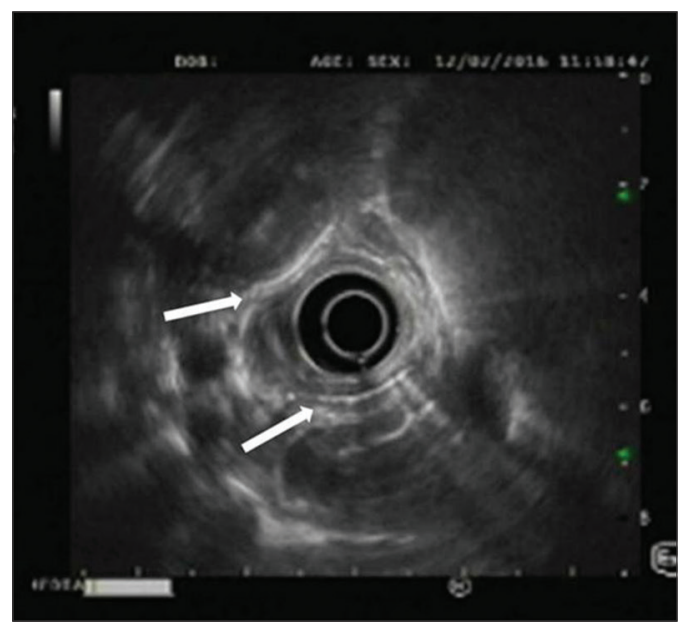

Figure 3: Radial endoscopic ultrasound image showing a lesion at 8-10 O'clock location, loss of wall layer pattern can be seen

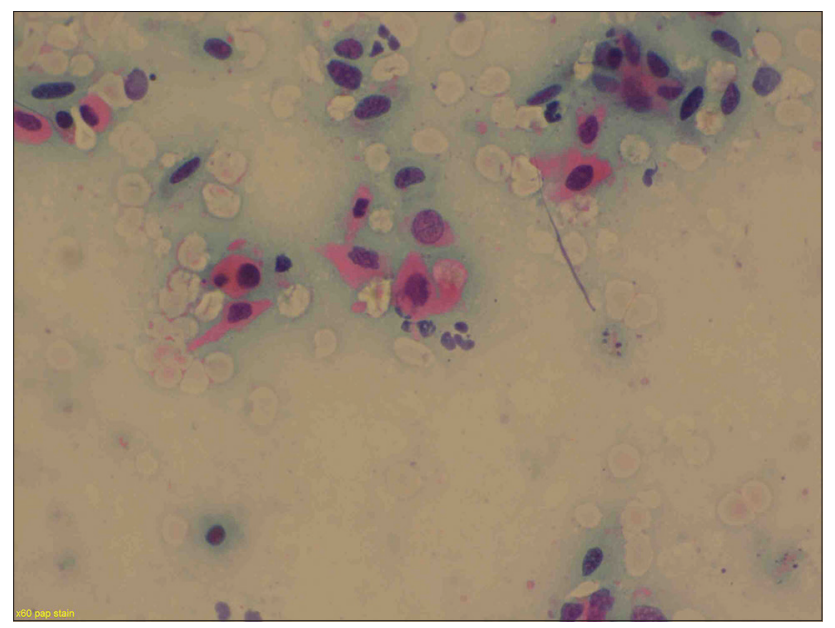

Figure 5: Malignant cells positive for keratin (orange color, PAP stain, 60 times magnification)

repeatedly negative mucosal biopsies that make it extremely uncommon presentation. Our report shows the importance of EUS-guided fine-needle aspiration of atypical submucosal lesions.

\section{Financial support and sponsorship Nil.}

\section{Conflicts of interest}

There are no conflicts of interest.

\section{References}

1. Chen J, Kwong DL, Cao T, Hu Q, Zhang L, Ming X, et al. Esophageal squamous cell carcinoma (ESCC): Advance in genomics and molecular genetics. Dis Esophagus 2015;28:84-9.

2. Kishino T, Yamaguchi Y, Yamagishi T, Hashimoto T, Kyomasu Y, Mori H, et al. Submucosal tumor (SMT)-like esophageal squamous cell carcinoma with gastric metastasis. Hepatogastroenterology 2000;47:1581-4.

3. Yates CW Jr., LeVine MA, Jensen KM. Varicoid carcinoma of the esophagus. Radiology 1977;122:605-8. 